\title{
Comparative Analysis of Dempster-Shafer Method and Certainty Factor Method On Personality Disorders Expert Systems
}

\author{
Doddy Teguh Yuwono ${ }^{1}$, Abdul Fadlil ${ }^{2}$, Sunardi $^{3}$ \\ ${ }^{1}$ Master of Informatics Engineering, Universitas Ahmad Dahlan, Yogyakarta, Indonesia \\ 2,3 Department of Electrical Engineering, Universitas Ahmad Dahlan, Yogyakarta, Indonesia \\ Email: 'doddy.zha09@gmail.com, ${ }^{2}$ fadlil@mti.uad.ac.id, ${ }^{3}$ sunardi@mti.uad.ac.id
}

\begin{abstract}
Artificial Intelligence technology has now been widely applied to various types of health problems that exist. The Expert System is one of the media to solve it. Personality Disorder is a way of thinking, feeling, and behaving that makes people different from others. Everyone has previously published topics choosing to turn them over from finding solutions to overcome them. Without treatment and handling that is truly ordinary, it will take into account that everything that is done is truly deviant in general. In this study, discussing to develop expert systems that can diagnose a person's personality disorder, by comparing the Dempster-Shafer method and the Certainty Factor method in determining the accuracy of personality disorders. The Dempster-Shafer method uses expert weight values which are the basis of system knowledge, while the Certainty Factor method has several variables that are used as systematic knowledge, namely expert weight values which are the basis of system knowledge and user input weight values. In the study, there were 20 medical records from the Counseling Guidance Laboratory of the Muhammadiyah Palangkaraya University that were used. The test results show that the Dempster-Shafer Method has accuracy in diagnosing disease up to $90 \%$, while the Certainty Factor method of system accuracy is $85 \%$. So it can be concluded that the Dempster-Shafer method is more accurate in diagnosing Personality Disorders
\end{abstract}

Keywords: Expert System, Disorders Personality, Dempster-Shafer, Certainty Factor.

\section{INTRODUCTION}

Expert System is a knowledge-based program that provides expert quality solutions for problems in a specific domain [1]. There are 2 methods with factors that determine the weighting value of personality disorders, namely: DempsterShafer and Certainty Factor. Both of these methods have different settlement processes and concepts, but the symptom data information that will be taken into account has similarities, as in each piece of information the two theories have an assessment taken from beliefs or hypotheses. Therefore the theory of Dempster- 
Shafer with Certainty Factor deserves to be compared with each other in order to know their respective shortcomings and strengths[2].

Certainty Factor was introduced by Shortliffe Buchanan in the making of MYCIN. Certainty Factor is the value of clinical parameters given by MYCIN to show the magnitude of trust [3]. MYCIN was the beginning of an expert system developed for five or six years in the early 1970s at Stanford University While Dempster-Shafer was first introduced by Arthur P. Dempster. Dempster-Shafer is a mathematical theory for proof based on belief functions and plausible reasoning, which is used to combine separate pieces of information (evidence) to calculate the probability of an event [4-5].

Diagnosis can be interpreted as an effort or process to find out what weaknesses or illnesses a person experiences by testing and studying others about their symptoms, careful study of the facts of things to find essential characteristics or errors and so on, decisions that are made after careful study of symptoms or facts about a matter is carried out [6].

The personality disorder is a condition that causes the sufferer to have an unhealthy and different mindset and behavior from the average person. In addition to an unhealthy mindset, conditions that are also categorized as mental illness can make it difficult for sufferers to feel, understand, or interact with others [6-7]. Through these two methods, it is possible to carry out a Personality Disorder Dignification. From each method used to analyze Personality Disorders, it can be concluded that these methods are effective and also feasible to diagnose personality disorders. In addition, these two methods have similarities in producing an analysis of a belief value. The following types of personality disorder:
1) Schizotypal
2) Schizoid
3) Paranoid
4) Borderline
5) Anti-Social
6) Narcissistic
7) Histrionic
8) Dependent
9) Avoid
10) Obsessive Compulsive

Based on the explanation above, the purpose of this research is to get the right method in making decisions and conclusions from the results of a personality disorder test consultation by patients based on the input symptoms.

\section{METHODS}

The method is needed to facilitate the researcher in carrying out the research stages. Each research uses a method. The methods that can be used in a study can 
be compared or combined. This study uses two methods to compare, namely the Dempster-Shafer method and the Certainty Factor method.

\subsection{Dempster-Shafer Method}

Dempster-Shafer (DS) is a mathematical theory for proof based on belief functions and plausible reasoning, which is used to combine separate pieces of information (evidence) to calculate the probability of an event [8-9]. The stages in the Dempster-Shafer method are [10-11]:

$$
\begin{aligned}
& m(X)=\operatorname{Bel}(X) \\
& m(\theta)=P l s(X)=1-\operatorname{Bel}(X)
\end{aligned}
$$

First is $\mathrm{m}(\mathrm{X})$ which is the density value of the symptom obtained from the bel value of Bel (X). Next, determine the value of the hypothesis Pls (X) of the symptom weight value as in equation (2). So as to produce a density value of $\mathrm{ml}$ and to obtain $\mathrm{m} 2$ it can be repeated again equation (1) and equation (2).

$$
m_{\text {Cobine }}=(m 1 \oplus m 2)=\frac{m 1(X) \cdot m 2(Y)}{m 1(\theta) \cdot m 2(\theta)}
$$

$\mathrm{m}_{\text {combine }}$ is the result of a combination of the values of density $\mathrm{m} 1$ and the density value of $\mathrm{m} 2$. From each result, the density value will be calculated which density has the highest confidence value in diagnosing a personality disorder.

\subsection{Certainty Factor Method}

Certainty Factor (CF) method is a method used to accommodate the inexact reasoning of an expert. An expert (such as a doctor) often analyzes the information available with an expression with uncertainty, to accommodate this we use CF to describe the level of expert confidence in the problem at hands[12]. In expressing the degree of certainty, $\mathrm{CF}$ assumes the degree of certainty of an expert on a data [2]. The following is a description of some combinations of Certainty Factor for various conditions [2, 13-15]:

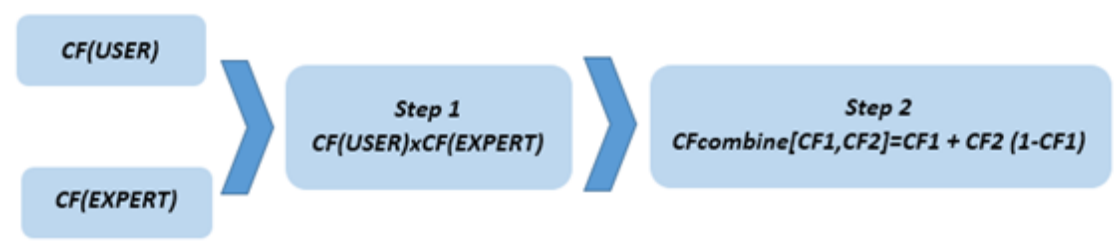

Figure 1. The step of the of method

Where $C F$ (expert) is $\mathrm{CF}$ of the $\mathrm{CF}$ value given by the expert (between 0 and 1 ) and $C F$ (user) is inputting the $\mathrm{CF}$ value from the user input. In step 1, the calculation is done by multiplying the second input, that is, $\mathrm{CF}$ users and $\mathrm{CF}$ 
experts with the results of the values obtained will be accommodated to CF1, and to get the value of $C F 2$ it is necessary to repeat step 1 . The next step in step 2 starts with the product has been done in step $1[3,16]$.

\section{RESULT AND DISCUSSION}

This research requires knowledge from experts to analyze the correct method for diagnosing a Personality disorder. Experts in this research were a psychologist, These psychologists are psychologists who work in the counseling laboratory of the Muhammadiyah University of Palangka Raya who handle various kinds of problems related to Psychology. The results of expert interviews and literature review from Diagnostic and Statistical Manual of Mental Disorders: DSM-5 are knowledge base consisting of symptoms of a Personality disorder, ten types of Personality Disorder diseases, and symptom weight scores for each symptom.

\subsection{Identification Data}

The population in this study was a symptom of any personality disorder where this study took 20 personality disorders with a total number of symptoms, 39 symptoms originating from the results of a literature study and interviews with experts. The research sample will be used to test the accuracy of the application in the application of the Dempster-Shafer method and the Certainty Factor method, there were 20 medical records from the Counseling Guidance Laboratory of the Muhammadiyah Palangkaraya University that were used. Through this knowledge acquisition process, it was concluded that the data obtained were 10 types of personality disorders and 39 accompanying symptoms. Rules for drawing conclusions are based on data obtained and directs users to solve problems. Data on the types of personality disorders obtained in Table 1.

Table 1. Personality disorder

\begin{tabular}{ccc}
\hline No & Personality disorder ID & $\begin{array}{c}\text { Name Of } \\
\text { Personality disorder }\end{array}$ \\
\hline 1 & A & Paranoid \\
2 & B & Schizoid \\
3 & C & Histrionic \\
4 & D & Schizotypal \\
5 & E & Narcissi \\
6 & F & Antisocial \\
7 & G & Borderline \\
8 & H & Avoidant \\
9 & I & Dependent \\
10 & J & Obsessive-compulsive \\
\hline
\end{tabular}

The weighting of each symptom will be carried out before the symptom data implementation process. A weight value is obtained from the expert by giving confidence values from each symptom, describing the weight values such as Table 2. 
Table 2. Weight value from the expert

\begin{tabular}{ccc}
\hline No & Personality disorder ID & Name Of Personality disorder \\
\hline 1 & No & 0 \\
2 & Do not know & 0,2 \\
3 & A little sure & 0,4 \\
4 & Sure enough & 0,6 \\
5 & Sure & 0,8 \\
6 & Very confident & 1 \\
\hline
\end{tabular}

This weighting is done to determine the size of the assessment of a symptom. The data obtained came from experts by looking at the data of all patients. Patient data obtained in the form of a short biography of the patient and supporting data of patients such as perceived symptoms and diagnosis of the disorder suffered. Weighting is carried out for each symptom and then processed according to the knowledge base of each symptom. Data symptoms of Personality Disorder in Table 3 .

Table 3. Data symptom

\begin{tabular}{|c|c|c|c|}
\hline No & Symptom ID & Symptom & Weight Value \\
\hline 1 & $\mathrm{G} 01$ & Many Suspicions Against Others & 0.6 \\
\hline 2 & G02 & Be Rude & 0.8 \\
\hline 3 & G03 & Difficulty socializing with other people & 0.8 \\
\hline 4 & G04 & Don't trust close friends that they can be trusted. & 0.6 \\
\hline 5 & G05 & Uninterested or lacking in close relationships & 0.8 \\
\hline 6 & G06 & Lack of request for sex & 0.8 \\
\hline 7 & G07 & Being ignorant of other people's praise or criticism & 0.6 \\
\hline 8 & G08 & Only a little if you experience pleasure & 0.6 \\
\hline 9 & G09 & Excessive emotional expression & 0.6 \\
\hline 10 & G10 & very easy to suggest & 0.6 \\
\hline 11 & G11 & Empty and chronic feelings & 0.8 \\
\hline 12 & G12 & It's very difficult to control anger & 0.8 \\
\hline 13 & G13 & Strange speech patterns & 0.6 \\
\hline 14 & G14 & Have Less Familiar Friends & 0.6 \\
\hline 15 & G15 & Excessive Emotional Expressions & 0.8 \\
\hline 16 & G16 & Extreme needs to be praised & 0.8 \\
\hline 17 & G17 & Envy others & 0.8 \\
\hline 18 & G18 & The tendency to use other people & 0.8 \\
\hline 19 & G19 & Focus on success & 0.8 \\
\hline 20 & $\mathrm{G} 20$ & Self-intelligence and beauty & 0.8 \\
\hline 21 & $\mathrm{G} 21$ & A strong feeling that they deserve something & 0.6 \\
\hline 22 & G22 & Irritable and aggressive & 0.6 \\
\hline 23 & $\mathrm{G} 23$ & lack of remorse & 0.6 \\
\hline 24 & $\mathrm{G} 24$ & Do not care for the safety of yourself and others & 0.8 \\
\hline 25 & G25 & Unstable emotions and behavior & 0.8 \\
\hline 26 & G26 & It's very difficult to control anger & 0.8 \\
\hline 27 & $\mathrm{G} 27$ & Impulsive behavior & 0.8 \\
\hline 28 & $\mathrm{G} 28$ & $\begin{array}{l}\text { Including very wasteful and inappropriate sexual } \\
\text { behavior }\end{array}$ & 0.8 \\
\hline 29 & G29 & Feel Inferior & 0.6 \\
\hline 30 & G30 & Limiting yourself in intimate relationships for fear of & 0.8 \\
\hline
\end{tabular}




\begin{tabular}{lccc}
\hline G31 & $\begin{array}{c}\text { being humiliated or ridiculed } \\
\text { Reluctance to live in relationships with other people } \\
\text { unless he will be liked. }\end{array}$ & 0.8 \\
32 & G32 & $\begin{array}{c}\text { Difficult to make decisions without excessive advice } \\
\text { and support from others }\end{array}$ & 0.8 \\
33 & G33 & It's hard to do everything yourself & 0.8 \\
34 & G34 & Lack of confidence & 0.8 \\
35 & G35 & Need someone else & 0.8 \\
36 & G36 & Inflexible about morals & 0.6 \\
37 & G37 & Miserly & 0.8 \\
38 & G38 & Excessive dedication to work to ignore pleasure and & 0.8 \\
39 & G39 & Triendship & 0.8 \\
\hline
\end{tabular}

\subsection{Decision diagrams}

Decision diagrams are used to simplify describing the rules in the system. The illustrated decision diagram in an expert system in Figure 1.

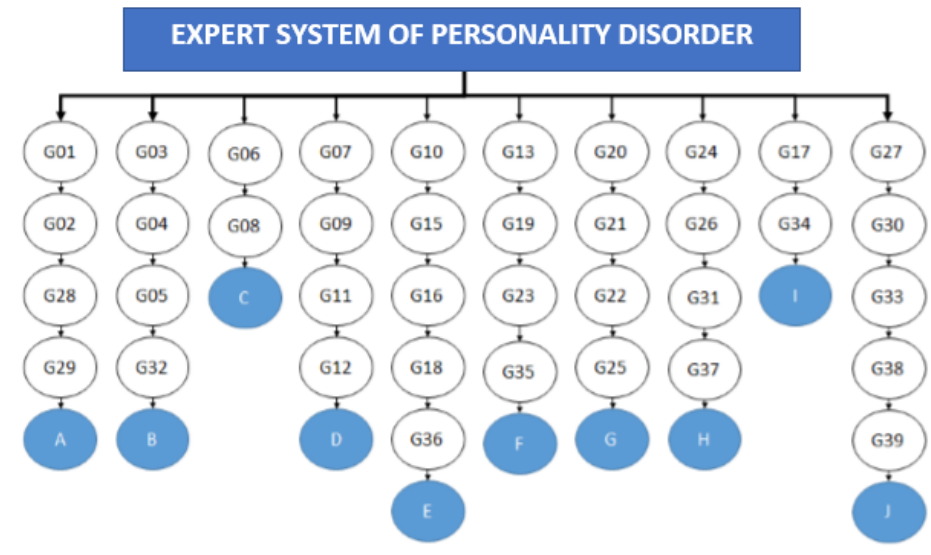

Figure 2. Illustrated decision diagram in expert systems

Figure 1, describes the symptoms that refer to Personality Disorders suffered. So that it can be concluded that each Personality Disorder has its own Symptoms

\subsection{Calculation-Based}

For example, The user input 3 symptoms with a weight value as in Table 4.

Table 4. Weight value from the expert

\begin{tabular}{ccc}
\hline No & Symptom Name & $\begin{array}{c}\text { Value of User } \\
\text { Possibilities }\end{array}$ \\
\hline 1 & Many Suspicions Against Others & 0.8 \\
2 & Be Rude & 0,6 \\
3 & Including very wasteful and inappropriate sexual behavior & 0,8 \\
\hline
\end{tabular}




\section{1) Dempster-Shafer Method}

The DS method uses the weight given by the expert weight value in Table 4 . The first step in calculating the DS is to calculate the value of the belief and plausibility of the symptom1, the user's weight value and the expert weight value that can be seen in Table 5, the first step the density value of $\mathrm{m} 1$ (G1) is 0.8 and the density value of $\mathrm{ml}(\theta)$ is 0.2 . seen in Table 5 .

Table 5. The density value of $\mathrm{m} 1$ (G1)

\begin{tabular}{ccc}
\hline Symptom Name & $\mathrm{m} 1(\mathrm{G} 1)$ & $\mathrm{m} 1(\theta)$ \\
\hline & & $=1-\mathrm{m} 1(\mathrm{G} 1)$ \\
Many Suspicions Against Others & 0.8 & $=1-0.8$ \\
& & $=0.2$ \\
\hline
\end{tabular}

The second step calculates the value of belief and plausibility of the symptoms. In the second step, the value of $\mathrm{m} 2$ density (G2) is 0.6 and the density value of $\mathrm{m} 2$ $(\theta)$ is 0.4 as shown in Table 6 .

Table 6 . The density value of $\mathrm{m} 2(\mathrm{G} 2)$

\begin{tabular}{ccl}
\hline Symptom Name & $\mathrm{m} 2(\mathrm{G} 2)$ & $\mathrm{m} 2(\theta)$ \\
\hline Be rude & & $=1-\mathrm{m} 1(\mathrm{G} 1)$ \\
& 0.6 & $=1-0.6$ \\
& & $=0.4$ \\
\hline
\end{tabular}

Next, use equation 3 to form a combination function $\mathrm{m} 1$ and $\mathrm{m} 2$ as $\mathrm{m} 3$ shown in Table 7.

Table 7. Combination function

\begin{tabular}{ccc}
\hline & $\mathrm{m} 2\{\mathrm{~A}\}$ & $\mathrm{m} 2\{\theta\}$ \\
0.6 & 0.4 \\
\hline $\mathrm{m} 1\{\mathrm{~A}, \mathrm{~B}, \mathrm{C}\}$ & $\mathrm{m} 3\{\mathrm{~A}\}$ & $\mathrm{m} 3\{\mathrm{~A}, \mathrm{~B}, \mathrm{C}\}$ \\
0.8 & 0.48 & 0.32 \\
& & \\
$\mathrm{~m} 1\{\theta\}$ & $\mathrm{m} 3\{\mathrm{~A}\}$ & $\mathrm{m} 3\{\theta\}$ \\
0.2 & 0.12 & 0.08 \\
\hline
\end{tabular}

The Summation of Dempster Shafer Theory :

$$
\begin{array}{ll}
\mathrm{m} 3\{\mathrm{~A}\} & =(0.48+0.12) /(1-0) \\
\mathrm{m} 3\{\mathrm{~A}, \mathrm{~B}, \mathrm{C}\} & =0.6 \\
\mathrm{~m} 3\{\theta\} & =0.32
\end{array}
$$

Calculate the value of belief and plausibility of the symptoms3, get the density value of $\mathrm{m} 4(\mathrm{G} 3)$ of 0.8 and the density value of $\mathrm{m} 4(\theta)$ of 0.2 . as shown in table 8. 
Table 8 . The density value of $\mathrm{m} 4(\mathrm{G} 3)$

\begin{tabular}{ccc}
\hline Symptom Name & $\mathrm{m} 4(\mathrm{G} 3)$ & $\mathrm{m} 4(\theta)$ \\
\hline Including very wasteful and & & $=1-\mathrm{m} 1(\mathrm{G} 1)$ \\
inappropriate sexual behavior & 0.8 & $=1-0.8$ \\
& & $=0.2$ \\
\hline
\end{tabular}

Next by using equation 3 to form the combination function $\mathrm{m} 3$ as $\mathrm{m} 4$ as shown in Table 9.

Table 9. Combination function

\begin{tabular}{ccc}
\hline & $\mathrm{m} 4(\mathrm{~A})$ & $\mathrm{m} 4(\theta)$ \\
& 0.8 & 0.2 \\
$\mathrm{~m} 3\{\mathrm{~A}\}$ & $\mathrm{m} 5\{\mathrm{~A}\}$ & $\mathrm{m} 5\{\mathrm{~A}\}$ \\
0.6 & 0.48 & 0.024 \\
& & \\
$\mathrm{~m} 3(\mathrm{~A}, \mathrm{~B}, \mathrm{C})$ & $\mathrm{m} 5(\mathrm{~A})$ & $\mathrm{m} 5(\mathrm{~A}, \mathrm{~B}, \mathrm{C})$ \\
0.32 & 0.256 & 0.064 \\
& & \\
$\mathrm{~m} 3(\theta)$ & $\mathrm{m} 5(\mathrm{~A})$ & $\mathrm{m} 5(\theta)$ \\
0.08 & 0.064 & 0.016 \\
\hline
\end{tabular}

The Summation of Dempster-Shafer Theory :

$$
\begin{array}{ll}
\mathrm{m} 5\{\mathrm{~A}\} & =(0.48+0.024+0.256+0.064) /(1-0) \\
\mathrm{m} 5\{\mathrm{~A}, \mathrm{~B}, \mathrm{C}\} & =0.824 \\
\mathrm{~m} 5\{\theta\} & =0.064
\end{array}
$$

Base on Table 11, it is known that the possibility of users experiencing Paranoid with a value of 0.824

\section{2) Certainty Factor Method}

The CF method utilizes the weight given by the user then combined with the expert weight values in Table 4. The first step in calculating CF is to multiply the two weight values, the user weight value and the expert weight value which can be seen in Table 10, then second step combining the CF values obtained from multiplying in the first step can be in Table 11, the following calculating steps for Paranoid using the user weight value or user input in Table 4.

Table 10. Weight value from the expert

\begin{tabular}{cccc}
\hline Symptom Name & $\begin{array}{c}\text { Expert Weight } \\
\text { Value }\end{array}$ & $\begin{array}{c}\text { Value Of User } \\
\text { Possibility }\end{array}$ & Multiplication \\
\hline Many Suspicions Against Others & 0.6 & 0.8 & 0.48 \\
Be Rude & 0.8 & 0.6 & 0,48 \\
Including very wasteful and & 0.8 & 0.8 & 0,64 \\
inappropriate sexual behavior & & 0.8 \\
\hline
\end{tabular}


Table 11. Combinations results

\begin{tabular}{ccc}
\hline Symptom Name & $\begin{array}{c}\text { CF Value of } \\
\text { Symptoms }\end{array}$ & CF Combination \\
\hline Many Suspicions Against Others & 0.48 & $=$ CF1+CF2 $(1-$ CF1 $)$ \\
Be Rude & & $=0.48+0.48(1-0.48)$ \\
& 0.48 & $=0.48+0.48(0.52)$ \\
& & $=0.78+0.2494$ \\
& & $=$ CF12 + CF3 $(1-$ CF12) \\
Including very wasteful and & & $=0.730+0.64(1-0.730)$ \\
inappropriate sexual behavior & 0.64 & $=0.730+0.64(0.27)$ \\
& & $=0.730+0.1728$ \\
& & $=0.813(\mathrm{CF} 123)$ \\
\hline
\end{tabular}

Base on Table 11, it is known that the possibility of users experiencing Paranoid with a value of 0.813 .

\subsection{System accuracy testing}

Table 4 shows the comparison of diagnosis results between the DS Method and the Certainty Factor method with the results of expert diagnosis on 20 patients. Where $\mathrm{P}$ is Patients, S is Symptom, DS is the calculation with DS, CF is the calculation with Certainty Factor, $\mathrm{X}$ is expert analysis results. as shown in Table 12.

Table 12. Accuracy testing

\begin{tabular}{|c|c|c|c|c|c|c|}
\hline \multirow{2}{*}{$\mathrm{P}$} & \multirow{2}{*}{ S } & \multirow{2}{*}{ DS } & \multirow{2}{*}{$\mathrm{CF}$} & \multirow{2}{*}{$X$} & \multicolumn{2}{|c|}{ Accuracy } \\
\hline & & & & & DS & $\mathrm{CF}$ \\
\hline P1 & $\begin{array}{l}\text { G01, G02, G03, G04, G06, G08, G09, G10, G15, G16, } \\
\text { G20, G22 }\end{array}$ & $\mathrm{E}$ & E & E & $\checkmark$ & $\checkmark$ \\
\hline P2 & $\begin{array}{l}\text { G01, G02, G03, G04, G06, G08, G09, G10, G12, G15, } \\
\text { G16, G18, G20, G22, G25, G26, G27 }\end{array}$ & $\mathrm{E}$ & $\mathrm{E}$ & E & $\checkmark$ & $\checkmark$ \\
\hline P3 & $\begin{array}{l}\text { G02, G03, G05, G07, G09, G10, G17, G19, G21, G25, } \\
\text { G27, G29, G37 }\end{array}$ & B & B & B & $\checkmark$ & $\checkmark$ \\
\hline P4 & $\begin{array}{l}\text { G01, G02, G04, G07, G09, G10, G17, G19, G21, G25, } \\
\text { G27, G28, G29 }\end{array}$ & A & A & A & $\checkmark$ & $\checkmark$ \\
\hline P5 & $\begin{array}{l}\text { G01, G04, G06, G08, G17, G19, G21, G23, G25, G27, } \\
\text { G30, G32, G35, G38, G39 }\end{array}$ & $\mathrm{J}$ & $\mathrm{J}$ & $\mathrm{J}$ & $\checkmark$ & $\checkmark$ \\
\hline P6 & $\begin{array}{l}\text { G01, G04, G06, G08, G09, G11, G13, G14, G15, G17, } \\
\text { G19, G20, G21, G23, G25, G27, G30, G32, G34, G35, } \\
\text { G39 }\end{array}$ & $\mathrm{D}$ & $\mathrm{D}$ & D & $\checkmark$ & $\checkmark$ \\
\hline P7 & $\begin{array}{l}\text { G01, G03, G04, G09, G10, G11, G13, G15, G17, G20, } \\
\text { G21, G23, G25, G27, G28, G30 }\end{array}$ & B & $\mathrm{G}$ & $\mathrm{G}$ & $x$ & $\checkmark$ \\
\hline P8 & $\begin{array}{l}\text { G01, G02, G03, G06, G08, G10, G12, G13, G15, G17, } \\
\text { G19, G21, G24, G26, G29, G30, G32, G36, G37 }\end{array}$ & $\mathrm{H}$ & $\mathrm{H}$ & $\mathrm{H}$ & $\checkmark$ & $\checkmark$ \\
\hline P9 & $\begin{array}{l}\text { G01, G03, G04, G06, G07, G09, G10, G13, G15, G17, } \\
\text { G18, G21, G23, G25, G27, G30, G32, G34 }\end{array}$ & $\mathrm{E}$ & B & $\mathrm{E}$ & $\checkmark$ & $\times$ \\
\hline P10 & $\begin{array}{l}\text { G01, G04, G06, G08, G14, G15, G17, G19, G20, G21, } \\
\text { G23, G25, G27, G30, G32, G34, G39 }\end{array}$ & $\mathrm{J}$ & $\mathrm{J}$ & $\mathrm{J}$ & $\checkmark$ & $\checkmark$ \\
\hline
\end{tabular}




\begin{tabular}{|c|c|c|c|c|c|c|}
\hline P11 & $\begin{array}{l}\text { G03, G06, G08, G10, G12, G13, G15, G19, G21, G24, } \\
\text { G26, G29, G30, G32, G36, G37 }\end{array}$ & $\mathrm{H}$ & $\mathrm{H}$ & $\mathrm{H}$ & $\checkmark$ & $\checkmark$ \\
\hline P12 & $\begin{array}{l}\text { G04, G06, G08, G09, G11, G13, G14, G15, G17, G19, } \\
\text { G20, G21, G23, G25, G27, G30, G32, G34, G35 }\end{array}$ & D & D & $\begin{array}{l}\mathrm{D} \\
\mathrm{F}\end{array}$ & $\checkmark$ & $\checkmark$ \\
\hline P13 & $\begin{array}{l}\text { G01, G02, G03, G04, G06, G09, G10, G13, G15, G17, } \\
\text { G18, G21, G23, G25, G28, G29, G32 }\end{array}$ & A & B & A & $\checkmark$ & $x$ \\
\hline P14 & $\begin{array}{l}\text { G01, G09, G10, G11, G13, G15, G17, G20, G21, G23, } \\
\text { G25, G27, G30, G32, G34, G35 }\end{array}$ & G & G & G & $\checkmark$ & $\checkmark$ \\
\hline P15 & $\begin{array}{l}\text { G08, G14, G15, G17, G19, G20, G21, G23, G25, G27, } \\
\text { G30, G32, G34, G38, G39 }\end{array}$ & $\mathrm{J}$ & $\mathrm{J}$ & $\mathrm{J}$ & $\checkmark$ & $\checkmark$ \\
\hline P16 & $\begin{array}{l}\text { G01, G03, G04, G06, G08, G12, G13, G15, G17, G19, } \\
\text { G21, G24, G29, G32, G34, G37 }\end{array}$ & I & B & B & $x$ & $\checkmark$ \\
\hline P17 & $\begin{array}{l}\text { G01, G02, G03, G06, G09, G10, G13, G15, G17, G21, } \\
\text { G25, G28, G29, G34, G35 }\end{array}$ & A & A & A & $\checkmark$ & $\checkmark$ \\
\hline P18 & $\begin{array}{l}\text { G03, G04, G11, G14, G17, G19, G20, G23, G25, G27, } \\
\text { G29, G31, G32, G33, G37 }\end{array}$ & B & B & B & $\checkmark$ & $\checkmark$ \\
\hline P19 & $\begin{array}{l}\text { G01, G03, G06, G09, G10, G12, G13, G15, G19, G21, } \\
\text { G24, G25, G28, G29, G34 }\end{array}$ & $\mathrm{F}$ & B & F & $\checkmark$ & $x$ \\
\hline P20 & $\begin{array}{l}\mathrm{G} 02, \mathrm{G} 06, \mathrm{G} 08, \mathrm{G} 10, \mathrm{G} 12, \mathrm{G} 15, \mathrm{G} 17, \mathrm{G} 19, \mathrm{G} 21, \mathrm{G} 24 \text {, } \\
\mathrm{G} 26, \mathrm{G} 29, \mathrm{G} 32, \mathrm{G} 33\end{array}$ & $\mathrm{H}$ & $\mathrm{H}$ & $\mathrm{H}$ & $\checkmark$ & $\checkmark$ \\
\hline
\end{tabular}

Accuracy value by using equation 7 . The accuracy value of the Dempster-Shafer method in cases of patients 1 to 20 has 18 suitable cases and 2 incompatible cases, namely the cases P7 and P16, the accuracy value is $90 \%$. Whereas for the Certainty Factor method there are 17 suitable cases and 3 inappropriate cases, namely in the cases of P9, P13, and P19. The accuracy value of the Certainty Factor method is $85 \%$.

\section{CONCLUSION}

Diagnosis results are obtained through the calculation process of the DempsterShafer method and Certainty Factor. The process of both methods uses symptom weights assessment with personality disorders based on expert knowledge as a reference for comparison. The DS method only utilizes the value that the expert provides regardless of the user input value in the system for its calculation. The CF method has more variables in the calculation, namely the value of the expert weight and the value of the user weight, which then from the two values will be combined for the result. Accuracy results based on 20 patients data for The research can be concluded, from the results of the comparison of the validation of the calculation of the Dempster-Shafer and Certainty Factor methods with quantitative expert confidence assessment, yield 90\% accuracy in the DempsterShafer method and $85 \%$ in the Certainty Factor method.

\section{REFERENCES}

[1] Kusumadewi, S. (2003). Informatika Sistem Pakar (Expert System). Informatika.Web.Id, pp. 2-3.

[2] Riolan, E. (2015). Analisa Perbandingan Metode Dempster-Shafer Dengan Metode Certainty Factor Pada Diagnosa Penyakit Anak. 3(065111299), 1-12.

[3] Setyaputri, K.E., \& Fadlil, A. (2018). Analisis Metode Certainty Factor 
pada Sistem Pakar Diagnosa Penyakit THT. 10(1), 30-35.

[4] Sinaga, M. D., Sari, N., \& Sembiring, B. (2016). Penerapan Metode Dempster Shafer Untuk Mendiagnosa Penyakit Dari Akibat Bakteri Salmonella. Cogito Smart J, 2(2), 94-107.

[5] Abdellatif, B., Boudraa, A.O., Osswald, C., \& Boucher, J.M. (2011). Comparison and improvement of Dempster-Shafer models. WISP 2011 IEEE Int. Symp. Intell. Signal Process. Proc., 20-24.

[6] American Psychiatric Association. (2013). Diagnostic and Statistical Manual of Mental Disorders: DSM-5, Am. Psychiatr. Assoc., p. 991.

[7] Rao, V.K., Prakash, V.C., Jyothsana, A., Sainadh, T., \& Harshitha, P. (2018). Assessing Psychological Factors of a Student Through Concentration Game for Career Selection. 7, 443-445.

[8] Ayu, A., \& Hasibuan, N.A. (2017). Implementasi Metode Dempster Shafer Pada Sistem Pakar Diagnosa Penyakit Sepsis. KOMIK (Konferensi Nas. Teknol. Inf. dan Komputer), pp. 154-160.

[9] Torkzadeh Mahani, N., Dehghani, M., Mirian, M. S., Shakery, A., \& Taheri, K. (2018). Expert finding by the Dempster-Shafer theory for evidence combination. Expert Syst., 35(1), 1-13.

[10] Sagdoldanova, A., Atymtayeva, L., \& Yespolayeva, Z. (2017). Medicine Recommendation Technique by Using Dempster-Shafer Theory. 32(3), 27-32.

[11] Maseleno, A., \& Hasan, M. (2011). Avian Influenza (H5N1) Expert System using Dempster-Shafer Theory. Int. Conf. Informatics Dev., pp. 93-98.

[12] Setyaputri, K.E., \& Fadlil, A. (2018). Comparative Analysis of Certainty Factor Method and Bayes Probability Method on ENT Disease Expert System. 5(2), 205-212.

[13] Hamidi Ricky, P. H. S., \& Hengky, A. (2017). Analisis Perbandingan Sistem Pakar Dengan Metode Certainty Factor Dan Metode DempsterShafer Pada Penyakit Kelinci. J. Sist. dan Teknol. Inf., 1(2).

[14] Yuwono, D.T., Fadlil, A., \& Sunardi. (2017). Penerapan Metode Forward Chaining Dan Certainty Factor Pada Sistem Pakar. KLIK, 04(02), 136145.

[15] Insani, M. I., \& Putra, A.T. (2018). Implementation of Expert System for Diabetes Diseases using Naïve Bayes and Certainty Factor Methods. 5(2), 185-193.

[16] Rachmawati, E.Y., Prasetiyo, B., \& Arifudin, R. (2018). The Comparison between Bayes and Certainty Factor Method of Expert System in Early Diagnosis of Dengue Infection. 5(2), 159-170. 